Histological study on internal organs development of ... (Ketut Mahardika)

\title{
HISTOLOGICAL STUDY ON INTERNAL ORGANS DEVELOPMENT OF MANGROVE SNAPPER, Lutjanus argentimaculatus LARVAE
}

\author{
Ketut Mahardika\#, Indah Mastuti, Regina Melianawati, and Zafran \\ Research and Development Institute for Mariculture, Gondol, Bali \\ (Received 23 April 2012; Accepted 28 August 2012)
}

\begin{abstract}
Mangrove snapper, Lutjanus argentimaculatus is one of highly economic value of marine fish commodity. Culture of this species has been developed a few years ago. Basic data on biological aspect is still limited whereas those kinds of information are needed. Histological study to determine development of internal organs of the larvae of mangrove snapper was conducted. Amount of 15-20 larvae each from 1 day after DAH hatching (1 DAH) up to 30 days after hatching (30 DAH) were collected, fixed in Bouin's solution for 4- 6 hours and then transferred into $70 \%$ alcohol. The samples were then embedded in paraffin wax and the sections were stained with haematoxylineosin (H\&E). Results showed that the eye retina of the mangrove snapper larvae well developed on $3 \mathrm{DAH}$, whereas their digestive tract was on $5 \mathrm{DAH}$. Under this condition, the larvae started feeding as showed by present of natural food tissues in the intestine. Development of digestive tract and other internal organs reached their complete form like in adult fish after $20 \mathrm{DAH}$.
\end{abstract}

\section{KEYWORDS: histological, internal organs, larvae, mangrove snapper}

\section{INTRODUCTION}

Fishes are facing the determining process to survive and grow well in their initial life. It is characterized by substantial and dramatic changes in structure that take place over a relatively short period when the larvae encounter a complex and dynamic environment (Fuiman, 1996). Such morphological changes provide bases of the performance directly related to survival (Masuda, 2009).

Most fishes suffer high mortality during early development due to the existence of a critical period that was redefined by Shifa \& Mathias (1987) as deepest, sharpest and fastest physiological and ecological changes produced by shifting of energy source from endogenous to exogenous. Moreover, they ex- plained that shifting of energy source and imperfections of organs drive the larvae to the phase of the most sensitive to environmental factors. Therefore, conceiving the ontogenetic event on the digestive organs is a significant consideration to determine appropriate time of the first feeding. By the time of feeding, the visual cues become important to gain the ability to feed. It depends on the development of the optical elements of the eye and the synaptic connections between the neurones of the retina and their connections in visual brain centres (Shand et al., 1999).

Snapper Lutjanus spp., is one of widely cultured species in Asia that practiced in cage (Kongkeo et al., 2010). Therefore, snapperseedling is a potential deal to run to fulfil the

\# Corresponding author. Research and Development Institute for Mariculture, Jl. Br. Gondol, Kec. Gerokgak, Kab. Buleleng, Kotak Pos 140, Singaraja, Bali 81101, Indonesia. Tel.: +62 36292278 E-mail address: kmahardika@yahoo.com 
seed supply. However, the problem of low survival rate remains unsolved. Morphological studies of early development of Lutjanus argentimaculatus larvae have been carried out in Research Institute for Mariculture, GondolBali by Melianawati \& Imanto (2002) and Melianawati et al. (2003). Furthermore, detail features and description of larval development would contributes more to optimise larval rearing.

Histological would provides reliable technique to reveal the features of organism tissues. By analyzing the serial sections, process of larval development can be defined. This study focussed on the development of eyes and digestive tract of Lutjanus argentimaculatus by histological means. The objective of this study was to describe development of the eye and digestive tract of $L$. argentimaculatus.

\section{MATERIALS AND METHODS}

\section{Fish Samples}

Daily sample collection began from just after the egg hatched up to 30 days after hatching. The fertilized eggs were collected from natural spawning then stocked in $4 \mathrm{~m}^{3}$ outdoor concrete tank.

\section{Larval Rearing}

Larval rearing were conducted in outdoor tank, therefore the larvae received natural photoperiod. Nannochloropsis oculata were added as green water at two days post hatched (DAH) larvae. Likewise, rotifer Brachionus rotundiformis was given on $2 \mathrm{DAH}$ as live feed, the approximate density of given rotifer was 10 individuals $/ \mathrm{mL}$ and increased up to $15-20$ individual/mL on $10 \mathrm{DAH}$. On $12 \mathrm{DAH}$ water circulatory began to be activated. Wild captive copepod Acartia sp. were also given on $15 \mathrm{DAH}$

\section{Histological Observation}

Prior to histological process, amount 15- 20 larvae were taken from rearing tank every day for 30 days and fixed in Bouin's solution for 46 hours. Then, the fixed larvae were processed according to Gunarso (1989) with some modifications. The samples were dehydrated in alcohol (70\% 80\% 90\% 95\% 100\%), cleared in xylene, and embedded in paraffin. All embedding process was done using automatic tissue processor. Embedded-tissues were sectioned ( 3 to $5 \mu \mathrm{m}$ ) and stained with Hematoxylin and Eosin (H\&E). Histological observation was performed under light microscope at 40x magnification.

\section{RESULTS AND DISCUSSION}

\section{Eye Development}

The eyes of the fish were present as the egg hatched and continue to develop into perfect visual organ. The histological section of L. argentimaculatus larvae showed that the initial function of the eyes was on $3 \mathrm{DAH}$ indicated by the formation of complete retinal layers (Figure 1). On 1 DAH both of the lenses and retinal layer were present although the part of retinal layer was not been distinguishable yet (Figure 1a). Differentiation of retinal layer into
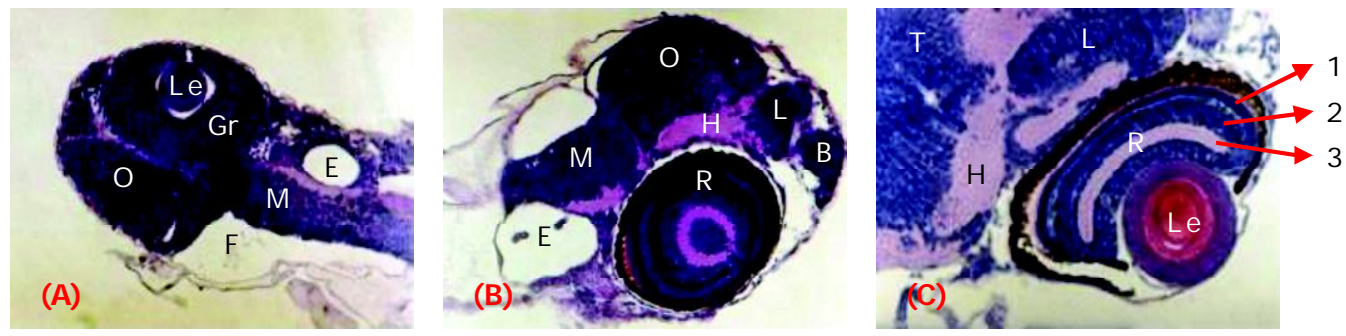

Figure 1. Histological section of red snapper larvae, L. argentimaculatus. (A). Sagittal section of the head larvae on 1 DAH the retina of eye is not complete yet (germinal retina), (B). Sagittal section of the head larvae on $2 \mathrm{DAH}$, the retina of eye appeared, (C). Sagittal section of the head larvae on $3 \mathrm{DAH}$, the retina of eye differentiates well. B: olfactory bulb, E: cavity of inner ear, F: membrane fin, $\mathrm{H}$ : hypothalamus, L: olfactory lobe, Le: lens of eye, M: medulla oblongata, $\mathrm{O}$ : optic lobe, R: retina of eye (1: pigment of ephitel, 2: rod and cones segment, 3: flexiform stage), T: thalamus. H- Estain, X 20- 40 
rod and cones segment were observed on 2 DAH (Figures $1 \mathrm{~b}$ ) and became complete layers on 3 DAH (Figure 1c). The sagittal section of the larvae (Figure 1) also showed the major part of the brain such as medulla oblongata, optic lobe, hypothalamus lobe, and olfactorius bulb began to develop on 2 DAH (Figure $2 b$ ).

The result of this study confirmed previous morphological study led by Melianawati \& Imanto (2002) revealing the perfect- pigmented eyes ware completed on $3 \mathrm{DAH}$. Histological study on red sea bream larvae revealed the retinal development began on $2 \mathrm{DAH}$ and completed on 4 DAH (Miyazaki et al., 1991). Other study on marble goby Oxyeleotris marmoratus, revealed that on $3 \mathrm{DAH}$ the eyes were perfectly pigmented and retina were completely differentiated into horizontal cells and cone elipsoid. Retina is the deepest layers of the eyes contained both of rod and cones photoreceptor therefore the eyes function well in dark and bright condition (Johnson, 1994). Development of eyes determined the capability of the larvae in response to the feed. In the initial life of larvae, capula have a role as sensory organ to external conditions before the eyes completely developed (Kawamura, 1991). Capula present in almost teleost fish is transparent series of neuron cord (laterosensory neuromast) along the head and body of fish which is sensitive to hydrodinamics in the environment (O'Conel, 1981).

\section{Digestive Tract and Internal Organs Development}

Development of digestive tract of $\mathrm{L}$. argentimaculatus larvae are showed in Figure
2. On 1 DAH the digestive tract appeared to be a straight tube along the oesophagus and anus (Figure 2a). Yolk sac containing colloidal yolk and oil globule were obviously observed with heavily eosin stained. On 2 DAH an enlargement tube cavity was observed at the posterior end of the tube. On other hand, liver undergoes initial development while the yolk sac became smaller (Figure 2b). The liver appeared as compact basophilic tissues attached to the yolk sac. On $3 \mathrm{DAH}$, the diameter of digestive tract increased and started to fold. The rectum was separated from the anterior intestine. A few remaining colloidal yolk was observed adjacent to the liver. Formation of swim bladder also initiated at 3 DAH (Figure 2c). Initial development of digestive tract of L. argentimaculatus was delay than development of the digestive tract of rainbow trout Oncorhynchus mykis larvae which digestive tract was attached to the anus a few hours after hatching. Moreover, on the second day their mouths were opened and the differentiation in the oeso phagus was started. On $2 \mathrm{DAH}$, the stomach was formed as continuing part of the oesophagus mucosa. Whereas, the liver sinusoids were observed on the first 3-4 DAH (Sarieyyupoglu et al., 2000).

Differentiated digestive tract was histologically observed on $5 \mathrm{DAH}$, the primordial stomach appeared at this time. It was connected to the oesophagus and extended to intestine and rectum. Swim bladder increased in size while the head kidney developed the tubule and haematocytes at the anterior side (Figure 3a). On $6 \mathrm{DAH}$, the colloidal yolk was completely absorbed. Sagittal section of the stomach in-
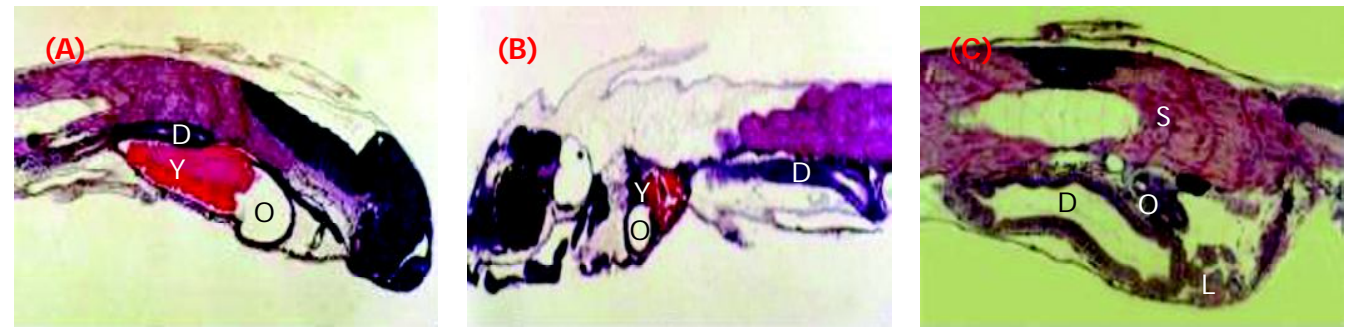

Figure 2. Histological section of red snapper larvae, L. argentimaculatus on 1- 3 DAH. (A). Sagittal section of larvae on $1 \mathrm{DAH}$. It has colloidal yolk and a big oil globule, which were walled off by thin viteline membrane and the intestine with straight tube shape, (B). Sagittal section of the larvae on $2 \mathrm{DAH}$. It has colloidal yolk and oil globule slightly decreased in size, (C). Sagittal section of the head of larvae on $3 \mathrm{DAH}$. The yolk markedly decreased in amount. The intestine increased in size. D: alimentary canal, L: liver, O: oil globule, S: swim bladder, Y: yolk 

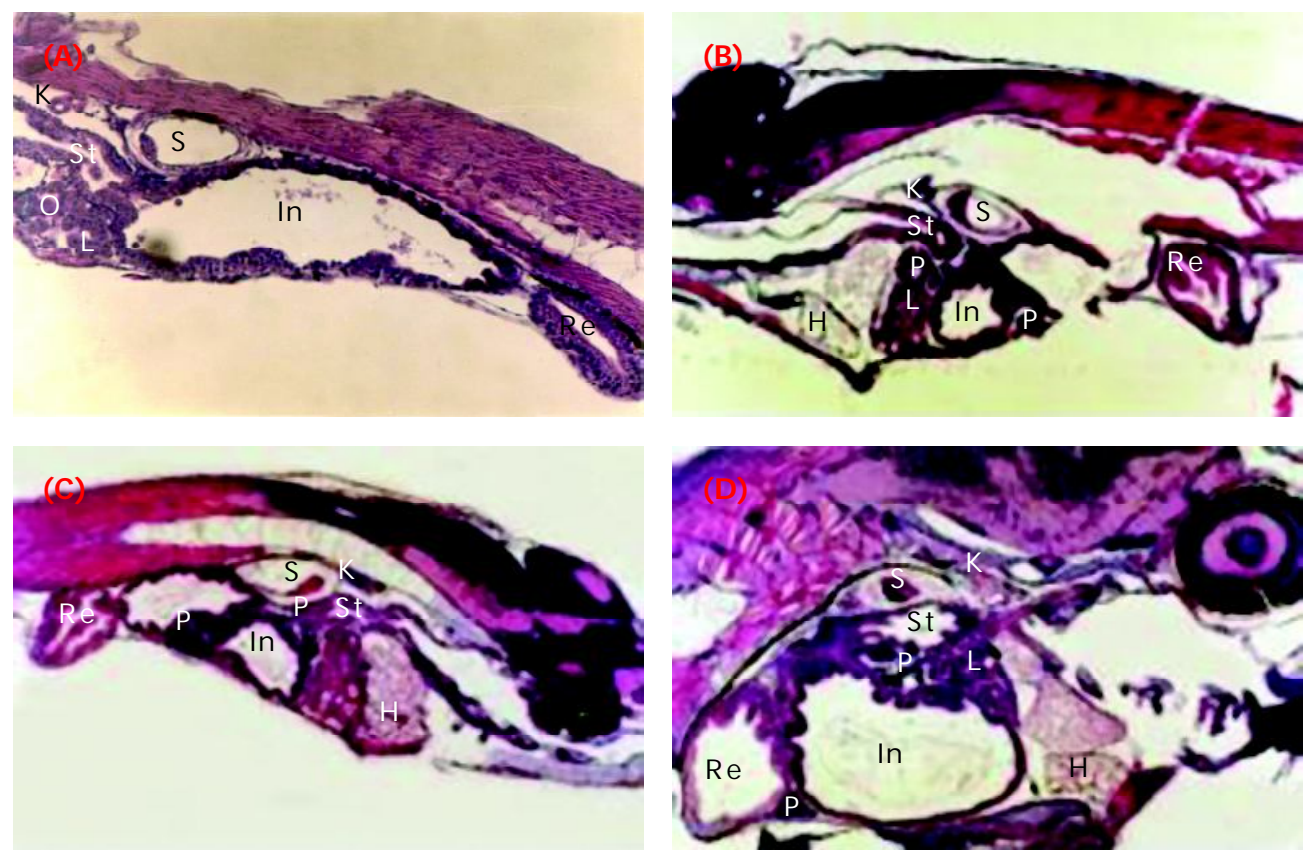

Figure 3. Histological section of red snapper larvae, L. argentimaculatus on 5- 13 DAH. (A). Sagittal section of larvae on 5 DAH shows differentiates well of digestive tract. The head kidney consists of renal tubules and hematopoitic cells, (B). Sagittal section of the larvae on $7 \mathrm{DAH}$. It has differentiated as well digestive tract, pancreatic cells containing zymogene granular, (C). Sagittal section of the larvae on 12 DAH shown differentiated digestive tract, (D). Sagittal section of the larvae on $13 \mathrm{DAH}$. Differentiated digestive tract and others organ. $\mathrm{H}$ : hearth, In: intestine, $\mathrm{K}$ : kidney, L: liver, O: oil globule, P: pancreas, Re: rectum, S: swim bladder, St: stomach

creased in volume and resembled to adult in shape. The intestine had phili (Figure 3c) that gain the capacity of nutrient absorbance. Pancreatic glands were present at the superior and inferior region of the intestine (Figure 3b). Remaining digested live feed was firstly observed at lumen of the gut at this time.

After $12 \mathrm{DAH}$, development of digestive tract mainly characterized by the increasing of folding mucosal layer (phili) at lumen of the intestine (Figure 3d). Phili protuded to the lumen with the increased diameter of the lumen, it was observed on $13 \mathrm{DAH}$.

Lipid vacoules (chyles) were present under the epithel layer, it increassed in number with the age of larvae (Figure $4 b$ and $4 c$ ). Developmet of L. argentimaculatus was almost completed on 18 DAH indicated by clearly observed associated organs (Figure 4a). Internal organs were completely developed as well as adult red snapper on $18 \mathrm{DAH}$.
Digestive tract and other internal organs are not totally mature at hatching; these organs undergo some morphological and functional changes during the development of the larvae. During the larval stage, the development of the alimentary tract changed from a straight, undifferentiated gut to a complex and segmented digestive tract. At the first exogenous feeding, it was partially differentiated except for the stomach that was lacking. The liver and the pancreas differentiated and became functional. Structural alternations occurring during the larval stage were related to teeth, muscle layers, and intestinal fold development (Abol- Munafi et al., 2006). In the larvae of gilthead seabream, Sparus aurata L., during yolk resorption, the digestive tract canged its shape and structure. Thus, from day 1 or 2 the posterior part opened, forming the anus. On day 3 , the formation of the loop commenced and the mouth opened showing two epithelial folds of flattened cells, surrounded by the oral 

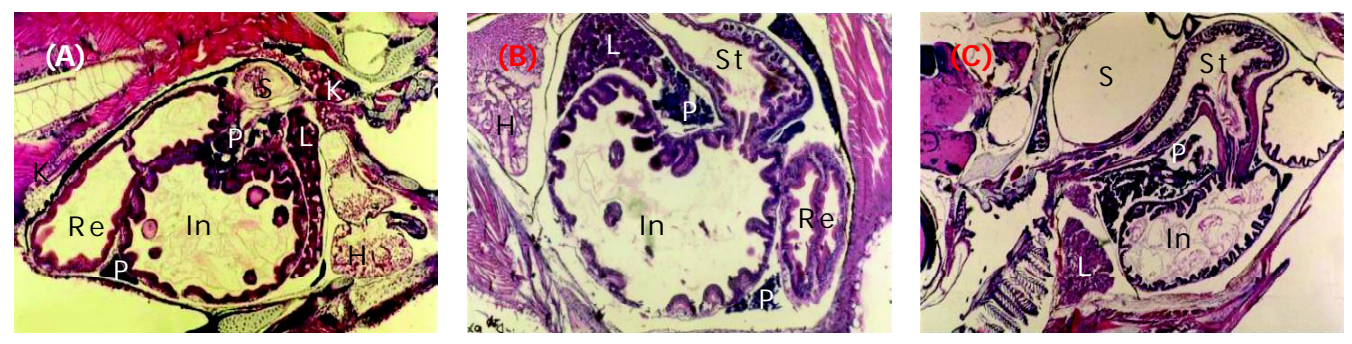

Figure 4. Histological section of red snapper larvae, L. argentimaculatus on 18-27 DAH. (A). Sagittal section of larvae on $18 \mathrm{DAH}$, (B). Sagittal section of the larvae on $21 \mathrm{DAH},(\mathrm{C})$. Sagittal section of the larvae on D- 27. All of figures showed that internal organs al ready differentiate well as in adult fish. $\mathrm{H}$ : hearth, In: intestine, K: kidney, L: liver, P: pancreas, Re: rectum, S: swim bladder, St: stomach

valves. At this time, three regions were clearly distinguished in the digestive tract: the foregut, whose single- layered epithelium consisted of cuboid cells; midgut (anterior intestine), lined with an epithelium consisting of cuboid or columnar cells and showing a striated acidophilic border; and the hindgut (posterior intestine), with a similar epithelium but ith shorter epithelial cells. The digestive tract was functional even though the stomach was not yet completely developed. The accessory glands were not apparent at hatching. The liver and pancreas were obserbed for the first time between day 2 and 3, taking the form of a cell cluster between the digestive tract and the yolk material (Sarasquete et al., 1995).

In marbled goby Oxyeleotris marmoratus larvae, the oesophagus differentiated on 2 $\mathrm{DAH}$. It was layered with squamous epithelium cell in the early larval stage and started to fold on $3 \mathrm{DAH}$. The changes during the larval development consisted of an increase in folding of the mucosa and in the number of mucous cells. At the onset of exogenous feeding, the stomach was not present but the zone from which the stomach will be differentiated could be identified. It was orientated caudally in the prolongation of the oesophagus. On 10- 15 $\mathrm{DAH}$, the stomach became more elongated and bent in its posterior region. The intestine that was identified as a section between stomach and the ileorectal valve started to develop on $1 \mathrm{DAH}$. It consisted a single layer of columnar epithelial cells. The epithelium started to fold on $2 \mathrm{DAH}$ and the thickness of the epithelium cells increased with fish age. Lipid vacuoles were observed in the posterior intestine on 7 $\mathrm{DAH}$. The rectum was separated from the anterior intestine by the ileorectal valve, which ap- peared in the larvae on $2 \mathrm{DAH}$. Organization of the rectal epithelium was similar to that of the intestine (Abol- Munafi et al., 2006).

Findings in other studies were similar to these from our present study which carried out under standard rearing conditions. Development of L. argentimaculatus digestive tract took time for about 20 days. In refer to this observation, the digestive tract was started to be functional on $3 \mathrm{DAH}$ and to be optimal on 5 $\mathrm{DAH}$, when the oesphagus and stomach were developed well. However, recent larval rearing practice generally gives initial feeding on $2 \mathrm{DAH}$. This constitutes a reference for further studies on rearing management particularly in feeding administration.

\section{REFERENCES}

Abol- Munafi, A.A.B., Liem, P.T., van, M.V., Ambak, M.A., Effendy, A.W.M., \&Soh, A.A. 2006. Histological ontogeny of the digestive system of marble boby (Oxyeleotris marmoratus) larvae. Journal of Sustainability Science and Management, 1(2): 79-86.

Fuiman, L.A. 1996. Dynamic morphology, phisiology and behaviour of fish larvae. Mar. Fresh. Behav. Phisiol., 28: 1-2.

Gunarso, W. 1989. Mikroteknik. Departemen Pendidikan dan Kebudayaan, Direktorat Jenderal Pendidikan Tinggi Pusat Antar Universitas IImu Hayat, Institut Pertanian Bogor, $117 \mathrm{pp}$.

Johnson, K.E. 1994. Seri kapita selekta histologi dan biologi sel. Alih bahasa Dr. F. Arifin Gunawan, M.S. Binarupa Aksara. P.O. Box 69, Grogol, Jakarta Barat, 230 pp.

Kawamura, G. 1991. Sensory organs. In Early development in fishes. (Ed.) Tanaka, M. 
Kouseisha Kouseikaku Tokyo, Japan, p. 920.

Kongkeo, H., Wayne, C., Murdjani, M., Bunliptanon, P., \& Chien, T. 2010. Current practice of marine finfish culture in China, Indonesia, Thailand and Vietnam. Marine Finfish Aquaculture Network, XV(2): 32-40.

Masuda, R. 2009. Behavioral ontogeny of marine pelagic fishes with the implications for the sustainable management of fisheries resources. Aqua-BioScie. Monogr. (ABSM), 2(2): 1- 56.

Melianawati, R. \& Imanto, P.T. 2002. Tabiat pemangsaan dan pemilihan pakan (Feeding Preference) pada larva ikan kakap merah. Laporan Teknis Penelitian Balai Besar Riset Perikanan Budidaya Laut Gondol, Bali. P. 243- 259.

Melianawati, R., Imanto, P.T., Setiawati, K.M., Swastika, M., \& Pratiwi, B.C. 2003. Produksi Kakap Merah dan Kerapu Macan dengan Penerapan Teknologi Resirkulasi. Laporan Teknis Balai Besar Riset Perikanan Budidaya Laut Gondol, Bali, p. 549- 557.

Miyazaki, T., Fujiwara, K., Oka, H.P., \& Yoshikawa, M. 1991. Histological studies on development of tissue and organs of larval and juvenile red sea bream. The Bul- letin of the Faculty of Bioresources, MIE University, Tsu, Japan, 5: 97- 116.

O'Connel, C.P. 1981. Development of the organ systems in the northern anchovy Engraulis mordax and other teleosts. American zoologist, 21: 429- 446.

Sarasquete, M.C., Polo, A., \& Yufera, M. 1985. Histology and Histochemistry of the development of the digestive system of larval gilt head seabream, Sparus aurata L. Aquqculture, 130: 79- 92.

Sarieyyupoglu, M., Girgin, A., \& Koprucu, S. 2000. Histological study in the digestive tract on larval development of rainbow trout (Oncorhynchus mykiss, Walbaum, 1792). Turk. J. Zool., 24: 199- 205.

Shand, J., Døving, K.B., \& Collin, S.P. 1999. Optics of the developing fish eye: comparisons of Matthiessen's ratio and the focal length of the lens in the black bream Acanthopagrus butcheri (Sparidae, Teleostei). Vision research, 39: 1,0711,078 .

Shifa, L. \& Mathias, J.A. 1987. The critical period of high mortality of larvae fish- A discussion bassed on current research. Chinese Journal of Oceanology and Limnology, 5(1): 80- 96. 